\title{
Munkahelyi stressz és megküzdési stratégiák vizsgálata földi és légi mentésben dolgozók körében
}

\author{
Schiszler Bence ${ }^{1}$ - Karamánné Pakai Annamária dr. ${ }^{2}$ \\ Szabó Zoltán ${ }^{3}$ - Raposa László Bence ${ }^{3}$ - Pónusz Róbert ${ }^{1}$ \\ Radnai Balázs dr. ${ }^{4}$ - Endrei Dóra dr. ${ }^{5}$ \\ ${ }^{1}$ Pécsi Tudományegyetem, Egészségtudományi Kar, Pécs \\ Pécsi Tudományegyetem, Egészségtudományi Kar, ${ }^{2}$ Képzési Központ, Ápolástudományi, \\ Alapozó Egészségtudományi és Védőnői Intézet, Szombathely, \\ ${ }^{3}$ Táplálkozástudományi és Dietetikai Intézet, Pécs, \\ ${ }^{4}$ Sürgősségi Ellátási és Egészségpedagógiai Intézet, Pécs, \\ ${ }^{5}$ Egészségbiztosítási Intézet, Pécs
}

\begin{abstract}
Bevezetés: A magyar egészségügyi szférában dolgozók körében köztudott a magas fokú stresszhatás jelenléte, amely kihathat az egyénre. Célkitüzés: A földi és légi mentésben dolgozók körében feltárni a munkahelyi stresszt, annak mértékét, illetve a pozitív és negatív megküzdési stratégiáikat. Módszer: 2015. júniustól októberig vizsgálták Magyarországon a földi és légi mentésben dolgozókat. Az adatgyújtést saját szerkesztésú, illetve a Rahe-féle, Rövidített Stressz- és Megküzdési Kérdőív segítségével online formában végezték. A kutatás keresztmetszeti típusú, kvantitatív jellegü volt $(\mathrm{n}=141)$. Az adatelemzés SPSS 20.0 statisztikai szoftverrel történt. Szignifikanciahatár p $<0,05$ volt. Eredmények: Nagyobb a munkahelyi stresszhatás jelenléte a földi mentésben dolgozóknál ( $<<0,01)$, nagyobb mértékben jelentkeznek náluk testi és pszichológiai tünetek $(\mathrm{p}<0,05)$. A Globális Stressz és Megküzdési Index alapján hatékonyabb copingmechanizmus figyelhető meg a légi mentésben dolgozóknál $(\mathrm{p}<0,01)$. Következtetések: Aránytalanság áll fenn a dolgozót ért stresszhatás és az azzal való megküzdési mechanizmus közt. A munkahelyi stressz csökkentésében a munkahelyek humán menedzsmentjének alapvető szerepe és érdeke is kell, hogy legyen. Orv. Hetil., 2016, 157(45), 1802-1808.
\end{abstract}

Kulcsszavak: munkahelyi stressz, megküzdés, mentés, mentődolgozók, légi mentés

\section{Examination of work-related stress and coping strategies among ambulance- and air-ambulance workers}

Introduction: Among Hungary's health sector workers the presence of a high level of stress is known, which can affect the individual. Aim: The aim of the authors was to uncover major risk factors causing work-related stress, as well as its extent, and positive and negative coping strategies among ground and aerial rescue workers. Method: From June until October 2015, a national survey was conducted among Hungarian rescue workers. An own questionnaire and Rahe Stress and coping validated short questionnaire online form were used. A total of 141 persons took part in the survey. Results: As compared to air-ambulance workers, ground rescue workers were exposed to higher work-related stress effects $(\mathrm{p}<0.01)$, resulting in a much larger variety of physical and psychological symptoms $(\mathrm{p}<0.05)$. Based on Global Stress and Coping Index effective coping mechanisms were observed among air rescue workers $(\mathrm{p}<0.01)$. Conclusions: It is important to perform regular professional theoretical and practical training. Human resource management should pay attention on occupational stress reduction.

Keywords: workplace stress, coping, rescue, rescue workers, air ambulance

Schiszler, B., K. Pakai, A., Szabó, Z., Raposa, L. B., Pónusz, R., Radnai, B., Endrei, D. [Examination of work-related stress and coping strategies among ambulance- and air-ambulance workers]. Orv. Hetil., 2016, 157(45), $1802-1808$.

(Beérkezett: 2016. július 27.; elfogadva: 2016. augusztus 25.) 
Napjainkban egyre több és mélyebbre hatóbb hazai és külföldi tanulmány foglalkozik a stresszel, munkahelyi stresszel és azok társadalmi és egészségkárosító hatásaival. Közismert, hogy az egészségügyi dolgozókat érintő - munkájukból adódó - stresszesemények negatív érzelmeket, valamint fiziológiai izgalmat váltanak ki [1]. Ezek komoly hatással vannak a szervezetre, és arra ösztönzik az elszenvedőt, hogy mielőbb csökkentse a negatív hatást. Ezek a változások sokáig reverzibilisek, azonban a stresszel való megküzdési kapacitás kimerülésével pszichés és testi tünetek is kialakulhatnak. Vizsgálatokból kiderül, hogy a hosszú távú munkahelyi stressz átélése depresszióhoz, szorongáshoz, poszttraumás stressz szindrómához vezethet $[2,3]$. Az egészségügyi dolgozók családi állapotának tekintetében elmondható, hogy kisebb százaléka él házasságban a civilekhez képest, és jóval magasabb közöttük az elváltak aránya is. Ennek oka a munka miatt átélt stresszel magyarázható. Ugyanakkor a magas társas támogatás nagymértékben csökkenti a munkahelyi stressz megjelenését és megélését [4]. A továbbiakban elmondható, hogy az elszenvedők többsége a problémaközpontú megküzdési stratégiákat használja, de az érzelemközpontú és a támogatást kereső megküzdési stratégiák is nagy gyakorisággal fordulnak elő [5]. Magyarországon az egészségügyet az alacsony bérezés és a társadalom általi csekély megbecsülés jellemzi. A megküzdési stratégiák közül a legerősebb kapcsolatrendszere a kognitív átstrukturálásnak van, amelyek megjelenését a jutalmak hiánya segíti elő, az erőfeszítések mennyisége pedig gátolja azt [6]. Sajnos kevesebb tanulmány foglalkozik a stressz már érezhető hatásainak kezelési stratégiáival, különös tekintettel a prehospitális szférában dolgozók körében. A stresszhatás ellen sokszor kialakult negatív megküzdés hosszú távon jelentős egészségkárosító hatást válthat ki. Ez idővel rossz minőségű életévekhez, korai halálozáshoz vezethet. Emellett a mindennapi életünk során számos olyan tényezővel is találkozhatunk, amelyek a munkahelyi stresszhatáson kívül stresszkeltőek lehetnek és hatást gyakorolnak az egyén életére, életminőségére [7-14].

\section{Módszer}

Kutatásunk keresztmetszeti típusú, prospektív elemeket tartalmazó, kvantitatív jellegû vizsgálat volt. Kizárólag azok a mentődolgozók vehettek részt a felmérésben, akik Magyarországon legalább 6 hónapja aktív kivonuló állományban lévő mentőorvos, mentőtiszt, paramedikus, mentőszakápoló, mentőgépkocsi-vezető pozícióban dolgozott a vizsgálat lebonyolításának időpontjában. A felmérés 2015 júniusától 2015 októberéig tartott. Kutatásunkban nem véletlenszerú célirányos mintaválasztást alkalmaztunk. Országos felmérést végeztünk a fent említett időszakban, ennek következtében konkrét helyszín nem került meghatározásra. Az adatgyưjtést egy saját szerkesztésű, valamint a Rabe-féle Rövidített Stressz- és Megküzdési Kérdőív magyar adaptációjának segítségével végeztük, amelynek validálását Rózsa Sándor és mtsai végezték el [15]. Saját készítésú kérdőívünk egyválaszos, zárt kérdéseket tartalmazó méróeszköz volt, amely a szociodemográfiai kérdéskörön túl az egészségi állapotot is vizsgálta mind fizikális, mind mentális oldalról. A kérdéskörök kitértek a mentőmunka során tapasztalt pszichés terhelés gyakoriságára, annak mindennapokra való kihatására. Vizsgálta a munka során tapasztalt stressz és magánélet kapcsolatát, a szabadidő mennyiségét. A Rabe-féle Rövidített Stressz- és Megküzdési Kérdőív magyar adaptációjának felhasználásával a krónikus stresszhatások és a rendelkezésre álló megküzdőkapacitások átfogó felmérését, illetve a két terület egymáshoz viszonyított mértékének megállapítását vizsgáltuk. A kérdőív felépítése az alábbiak szerint vázolható: stressz mérése 3 dimenzióban (testi tünetek, pszichológiai tünetek, magatartás és érzelmek feltárása), megküzdés mérése 5 dimenzióban (egészséggel kapcsolatos szokások, társas támogatottság, stresszre adott válasz, elégedettség az élettel, életcélok). A kérdőívben szereplő 8 dimenzió nyers pontszámai az egyes válaszok melletti pontszámok összeadásával számíthatók ki. Ezt követi a nyers pontszámok standard értékekbe történő átszámítása, amely a normáleloszlás kvartilisein alapul. Ha egy személy nyers pontszáma a legalacsonyabb kvartilisbe esik, akkor 0 pontot kap (kiváló szint), ha a legmagasabba, akkor 3-at (aggodalomra okot adó szint). A közbülső tartományok 1 (jó szint) és 2 (elégséges szint) pontot érnek. A stresszskálák standard pontjainak összeadásával az összesített stresszmutató számítható ki, a megküzdőkapacitást feltáró skálák összege pedig az összesített megküzdési mutatót eredményezi. A két összesített mutató különbsége alkotja a Globális Stressz és Megküzdési Indexet. A kérdőív magyar adaptációjának validálását követően a mérőeszköz megbízhatóságát és érvényességét jónak ítélték [15]. A beérkező 142 kérdőív közül 141 volt értékelhető.

Eredményeinket SPSS 20.0 verziójú statisztikai programmal elemeztük, leró statisztikát, $\chi^{2}$-, kétmintás t-próbát, Mann-Whitney-tesztet, korrelációszámítást, illetve varianciaanalízist alkalmaztunk. A szignifikanciaszintet p<0,05 értékben határoztuk meg, 95\%-os konfidenciaintervallum mellett (CI: 95\%) [16-18].

\section{Eredmények}

\section{A szociodemográfiai mutatók alakulása}

Vizsgálatunkban összesen 141 fó vett részt $(\mathrm{n}=141)$, a nemek megoszlása pedig a következőképpen alakult: A mintában szereplők $17 \%$-a nő $(\mathrm{n}=24)$ és $83 \%$ férfi ( $\mathrm{n}=117)$. A felmérésben részt vevőket életkoruk alapján 5 csoportba soroltuk a következők alapján: 20-25 évesek $(\mathrm{n}=13), 26-35$ évesek $(\mathrm{n}=52), 36-45$ évesek $(\mathrm{n}=56)$, 46-55 évesek $(\mathrm{n}=14)$, valamint 56-65 évesek $(\mathrm{n}=6)$. A mintában szereplők döntő többsége a 36-45 évesek csoportjából került ki $(39,7 \%, n=56)$. A különböző csa- 
ládi állapotok megjelenítésére négy kategóriát hoztunk létre: házastársi kapcsolatban élő $(\mathrm{n}=82)$, egyedülálló $(\mathrm{n}=25)$, élettársi kapcsolatban élő $(\mathrm{n}=34)$, valamint özvegy $(\mathrm{n}=0)$. Az iskolai végzettség szempontjából a mintában szereplők 30,5\%-a $(n=43)$ gimnáziumi/szakközépiskolai végzettséggel, 17\%-a (n = 24) OKJ-s szakképzettséggel, 47,5\%-a $(\mathrm{n}=67)$ föiskolai/egyetemi diplomával, illetve 5\%-a $(\mathrm{n}=7) \mathrm{PhD}$-doktori fokozattal rendelkezett a vizsgálat időpontjában. A munkahely típusa szerint - attól függően, hogy mentőállomáson vagy légi bázison teljesít szolgálatot a vizsgált személy - két csoportot különböztettünk meg. A válaszadók $60,3 \%$-a valamely magyarországi mentőállomáson ( $\mathrm{n}=85)$, 39,7\%-a (n = 56) az ország különböző légi bázisán kivonuló mentődolgozóként dolgozik. Betöltött munkakör szempontjából mentőorvost $(\mathrm{n}=35)$, mentőtisztet ( $\mathrm{n}=18)$, paramedikust $(\mathrm{n}=26)$, mentőszakápolót $(\mathrm{n}=40)$, mentőgépkocsi-vezetőt $(\mathrm{n}=22)$ különböztettünk meg a mintában. Felmérésünkbe be kívántuk vonni a mentőhelikopter-pilótákat is, azonban a vizsgálat időintervallumában nem érkezett értékelhető adat a légi mentésben dolgozók ezen alcsoportjától. A szociodemográfiai adatokat a két vizsgált csoport függvényében az 1. táblázat foglalja össze.

\section{A pszichés terhelés gyakoriságát vizsgáló kérdöí eredményei}

Mivel a kivonuló mentődolgozók munkájuk során gyakran találkoznak traumás eseményekkel, ezért kíváncsiak voltunk, hogy a mintában szereplők milyen gyakran tapasztalnak olyan „traumatikus” élményt, amely hatással van hétköznapjaikra. A „traumatikus” élmény alatt azokat - a munka során átélt - eseményeket értjük, amiket az érintett lelkileg nehezebben tud feldolgozni, megakadályozni, hogy érzelmeire hassanak. Ilyen „traumatikus” esemény lehet például egy gyermek sikertelen újraélesztése vagy tömeges baleseti kárhely felszámolásában való segédkezés. A válaszadók 14,9\%-a $(\mathrm{n}=21)$ jelölte meg a válaszlehetőségek közül azt, hogy naponta, míg a mintában szereplők 43,3\%-ánál ezek az események hetente jelentkeznek ( $\mathrm{n}=61)$. A megkérdezetteknek kevéssel több, mint negyede $(\mathrm{n}=38)$ tapasztal havonta olyan élményt, amely kihat érzéseire a mindennapok során. Akik csupán évente élnek át olyan eseményt, amely befolyásolja mindennapjaikat, azok a mintának 14,9\%-át képezték $(\mathrm{n}=21)$. A munkahely típusa (földi-légi mentés) nem befolyásolja azon pszichés élmények előfordulását, amelyek kihatnak a mentődolgozók mindennapjaira

1. táblázat |A minta összegzése demográfiai adatok szerint $(\mathrm{n}=141)$

\begin{tabular}{|c|c|c|c|c|}
\hline & \multicolumn{2}{|c|}{$\begin{array}{l}\text { Földi mentésben dolgozó } \\
(\mathrm{n}=85)\end{array}$} & \multicolumn{2}{|c|}{$\begin{array}{l}\text { Légi mentésben dolgozó } \\
(\mathrm{n}=56)\end{array}$} \\
\hline & Fö & $\%$ & Fö & $\%$ \\
\hline Elemszám & 85 & 60,3 & 56 & 39,7 \\
\hline \multirow[t]{2}{*}{ Átlagéletkor } & év & $\%$ & év & $\%$ \\
\hline & 41 & 37,6 & 34 & 53,6 \\
\hline Nem & fó & $\%$ & fó & $\%$ \\
\hline Férfi & 73 & 85,9 & 44 & 78,6 \\
\hline Nő & 12 & 14,1 & 12 & 21,4 \\
\hline \multicolumn{5}{|l|}{ Iskolai végzettség } \\
\hline Gimnázium/szakközépiskola/szakmunkásképző & 38 & 44,7 & 5 & 8,9 \\
\hline OKJ/felsőfokú szakképesítés & 19 & 22,4 & 5 & 8,9 \\
\hline Főiskola/egyetem & 26 & 30,6 & 41 & 73,2 \\
\hline Doktori (PhD) & 2 & 2,4 & 5 & 8,9 \\
\hline \multicolumn{5}{|l|}{ Családi állapot } \\
\hline Házas & 48 & 56,5 & 34 & 60,7 \\
\hline Élettársi kapcsolat & 19 & 22,4 & 15 & 26,8 \\
\hline Egyedülálló & 18 & 21,2 & 7 & 12,5 \\
\hline \multicolumn{5}{|l|}{ Munkakör } \\
\hline Orvos & 5 & 5,9 & 30 & 53,6 \\
\hline Mentőtiszt & 18 & 21,2 & 0 & 0 \\
\hline Paramedikus & 2 & 2,4 & 24 & 42,9 \\
\hline Mentőápoló & 38 & 44,7 & 2 & 3,6 \\
\hline Mentőgépkocsi-vezető & 22 & 25,9 & 0 & 0 \\
\hline
\end{tabular}


$(\mathrm{p}=0,394)$. Ugyanakkor az iskolai végzettség tekintetében összefüggés mutatkozott. Az eredményekből kiderült, hogy a mintában szereplők közül a gimnázium/ szakközépiskola/szakmunkásképző végzettséggel rendelkezők gyakrabban élnek át munkájuk során olyan "traumatikus" eseményt, amely hatással van hétköznapjaikra $(\mathrm{p}<0,05)$. Vizsgáltuk annak gyakoriságát, hogy egy átélt pszichés traumát követően milyen gyakran jelentkezik elalvási, átalvási nehézség. A megkérdezettek közel 40\%-ánál még soha nem fordult elő ilyesfajta probléma $(\mathrm{n}=56)$. Hasonló számban vannak azok, akik úgy nyilatkoztak, hogy ritkán, de előfordult $(\mathrm{n}=65)$ elalvási, átalvási nehézség. A vizsgált populáció kis hányadát képezték azok, akiknél gyakran $(\mathrm{n}=18)$, illetve nagyon gyakran $(\mathrm{n}=2)$ jelentkezett a fent említett tünet. Vizsgáltuk továbbá, hogy befolyással van-e az elalvási, átalvási nehézségek megjelenésére, hogy a mintában szereplő személy alacsonyabb (mentőgépkocsi, kiemelt mentőegység) vagy magasabb szintû mentőegységen (eset/roham kocsi, mentőhelikopter) teljesít szolgálatot. Az eredményekből kiderült, hogy a vizsgált személyek közül gyakrabban a mentögépkocsin $(\mathrm{p}<0,05)$, valamint mentőhelikopteren szolgálatot teljesítők $(\mathrm{p}<0,05)$ körében volt fellelhető az el-, illetve átalvási problémák jelentkezése.

\section{A Rabe-féle Röpiditett Stressz és Megküzdés Kérdöí eredményei}

\section{A krónikus stressz felmérése a mintában szereplő mentődolgozók körében}

$\mathrm{Az}$ összesített stresszmutató eredményeit tekintve elmondható, hogy a vizsgált két csoport közül nagyobb fokú munkahelyi stresszhatásnak vannak kitéve a földi mentésben dolgozók, szemben a légi mentésben szolgálatot teljesítőkhöz képest $(\mathrm{p}<0,05)$. A testi tünetek vizsgálatára az egészségi problémák 8 területét 3-3 kérdéskörrel tárja fel a Rahe-féle Rövidített Stressz és Megküzdés Kérdőív. Ezek a következők: légúti problémák, gyomor- és bélrendszeri problémák, szív- és érrendszeri problémák, általános egészségi állapot, mozgásszervi tünetek, idegrendszeri problémák, nemi és kiválasztó szervrendszeri zavarok, bőrproblémák. A kitöltőknek az elmúlt évet kellett alapul venniük a felsorolt problémák előfordulásának szempontjából. A vizsgálatban részt vevők stresszértékének kiszámítását követően kiderül, hogy a testi tünetek aspektusából a földi mentésben dolgozók körében a csoport 10,6\%-a ért el "jó" szintet $(n=9), 11,8 \%$ stresszérték alapján „elégséges”nek mondható $(\mathrm{n}=10)$, és a csoport nagyobb része, $77,6 \%$ „aggodalomra okot adó” szintet $(\mathrm{n}=66)$ ért el. A légi mentésben kivonulók közt az alábbi eredmények mutatkoztak: a stresszértékek alapján a csoport 33,9\%-a ért el „jó” szintet $(\mathrm{n}=19)$, „elégséges”-nek mondható a csoport 25\%-ánál a stressz-szint $(\mathrm{n}=14)$, és „aggodalomra okot adó" szintet ért el az értékek alapján a csoport 41,1\%-a $(n=23)$. Vizsgáltuk, hogy a különbözó testi tünetek megjelenését befolyásolja-e az, hogy a mintában szereplők milyen szintü mentőegységen teljesítenek szolgálatot. Az eredményekból megmutatkozott, hogy az obstipatio és hasmenés $(\mathrm{p}<0,05)$, az aranyeres panaszok $(p<0,01)$, a szívritmuszavar, $(p<0,01)$, illetve mellkasi diszkomfort érzés előfordulása $(\mathrm{p}<0,01)$ gyakoribb a mintában szereplő földi mentésben részt vevők körében, azon belül is a magasabb mentőegységnek számító eset/roham kocsin szolgálatot teljesítők közt. Mozgásszervi tünetek szempontjából: izomfájdalmak és -görcsök megjelenése $(\mathrm{p}<0,05)$, valamint gyakori derékés hátfájdalom megjelenése $(\mathrm{p}<0,01)$, idegrendszeri tünetek aspektusából: gyakori fejfájások $(\mathrm{p}<0,01)$ és szédüléses periódusok $(\mathrm{p}<0,01)$ megjelenése számottevőbb a földi mentésben dolgozók körében.

A pszichológiai tünetek vizsgálatára 12 kérdés irányul a Rahe-féle Rövidített Stressz és Megküzdés Kérdőívben, amelyből hat a depresszió, illetve a másik hat kérdés a szorongás feltárását célozza meg. Hasonlóan az előzőekhez, a mintában szereplóknek az elmúlt évet alapul véve kellett megítélniük a felsorolt problémák előfordulását. Az adatok feldolgozását követően kiderült, hogy „jó” szintű stresszérték mutatkozott közel azonos arányban, a vizsgálatban szereplő földi $(\mathrm{n}=22)$ és légi mentésben $(\mathrm{n}=23)$ dolgozók két csoportja között. Akiknél a stresszérték az „elégséges” kategóriát mutatta, azok alkották a földi mentésben részt vevők 21,2\%-át $(\mathrm{n}=18)$ és a légi mentésben szolgálók 26,8\%-át $(\mathrm{n}=15)$. Az eredmények azt mutatták, hogy a stresszértékek szempontjából nagy különbség mutatkozott a két csoport között abból a szempontból, hogy az érték alapján az „aggodalomra okot adó" kategóriába került. A földi mentésben szereplők közül többen kerültek ebbe a kategóriába $(\mathrm{n}=45)$, a légi mentésben dolgozók körében ez az arány jóval kisebb volt $(\mathrm{n}=18)$. Az adatok feldolgozását követően bebizonyosodott, hogy a mintában részt vevő földi mentésben dolgozók körében gyakoribb a depresszió és szorongás tüneteinek megjelenése $(\mathrm{p}<0,05)$, valamint rosszabbnak ítélték az egészségi állapotukat az elmúlt év során, szemben a légi mentésben dolgozókkal $(\mathrm{p}<0,01)$.

A magatartás és érzelmek viszonyának feltárására a Rahe-féle kérdőív 2 nagy csoportot különböztet meg, attól függően, hogy az A típusú (türelmetlen, versengő, lobbanékony természetú) vagy C típusú (higgadt, konfliktuskerülő természetű) viselkedésre utaló jellemzők mérésére irányultak a kérdések. Az A típusú viselkedés vizsgálatára 12 kérdés irányul, amely magába foglalja a munkahelyi magatartás, tempó, életszemlélet kérdéskörét. A C típusú viselkedés feltárására a kérdések a következőkre irányulnak: magabiztosság, érzelmek, illetve társas kapcsolatok. A vizsgálatban részt vevők stresszértékének kiszámítását követően megállapítható, hogy a magatartás és érzelmek aspektusából a földi mentésben dolgozók körében a csoport 18,8\%-a ért el „jó" szintet (n = 16), 11,8\% a stresszérték alapján „elégséges”-nek mondható $(\mathrm{n}=10)$, és a csoport nagyobb része, $69,4 \%$ 
„aggodalomra okot adó” szintet $(\mathrm{n}=59)$ ért el. A légi mentésben kivonulók között hasonló eredmények mutatkoztak, ugyanis a csoport 17,9\%-a ért el „jó” szintet $(\mathrm{n}=10)$, „elégséges"-nek mondható a csoport $21,4 \%$ ánál a stressz-szint $(\mathrm{n}=12)$, és az „aggodalomra okot adó" szintet érte el az értékek alapján a csoport $60,7 \%$-a $(\mathrm{n}=34)$. Ennek tükrében elmondható, hogy nem befolyásolja a magatartás és érzelmek vizsgálatára irányuló stresszpont alakulását az, hogy földi vagy légi mentésben dolgozik-e a vizsgált személy $(\mathrm{p}=0,570)$. A minta átlagos stresszmutató szerinti eredményeit a 2. táblázat foglalja össze.

2. táblázat |A minta jellemzése átlagos stresszmutató szerint $(\mathrm{n}=141)$

\begin{tabular}{lll}
\hline & \multicolumn{2}{l}{ Átlagos stresszmutató* } \\
\cline { 2 - 3 } & $\begin{array}{l}\text { Földi mentésben } \\
\text { dolgozók }\end{array}$ & $\begin{array}{l}\text { Légi mentésben } \\
\text { dolgozók }\end{array}$ \\
\cline { 2 - 3 } Testi tünetek & $\begin{array}{l}\text { Értékelés: 3 } \\
\text { (aggodalomra okot adó) }\end{array}$ & $\begin{array}{l}\text { Értékelés: 3 } \\
\text { (aggodalomra } \\
\text { okot adó) }\end{array}$ \\
\hline Pszichológiai tünetek & $\begin{array}{l}\text { Értékelés: 3 } \\
\text { (aggodalomra okot adó) }\end{array}$ & $\begin{array}{l}\text { Értékelés: 1 } \\
\text { (jó) }\end{array}$ \\
\hline Magatartás és érzelmek & $\begin{array}{l}\text { Értékelés: 3 } \\
\text { (aggodalomra okot adó) }\end{array}$ & $\begin{array}{l}\text { Értékelés: 3 } \\
\text { (aggodalomra } \\
\text { okot adó) }\end{array}$ \\
\hline
\end{tabular}

* A mérési skálák értékelése során a standard értékek jelentése: 0: kiváló, 1: jó, 2: elégséges, 3: aggodalomra okot adó. A magasabb elért átlagos stresszmutató magasabb stresszterheltséget jelent.

\section{A stresszel való megkïzdési mechanizmusok felmérésének eredményei}

A vizsgálatban alkalmazott Rahe-féle Rövidített Stressz és Megküzdés Kérdőívben a megküzdést feltáró skálák közül az első az egészséggel kapcsolatos szokások feltárását célozza. A 13 kérdést az alábbi négy kérdéskör foglalja magába: káros szenvedélyek, étrend, testmozgás, életritmus. Az összesített megküzdési mutató eredményei a következőkre világított rá: A dohányzási és alkoholfogyasztási szokásokat összevetve megmutatkozott, hogy a két csoport közül a légi mentésben dolgozók közt 16,2\%-kal kevesebb a rendszeres dohányzó és 25,2\%-kal az alkoholfogyasztók aránya, mint a földi mentésben szolgálatot teljesítők közt. Az élénkítő szerek (kávé, energiaital, koffeintabletta) használatának szemszögéből kiderült, hogy ugyan mind a két csoportnál kevesebb a rendszeresen fogyasztók száma, azonban elmondható, hogy a légi mentésben dolgozók körében $23,4 \%$-kal gyakoribb a használók aránya $(\mathrm{n}=25)$, mint a földi mentésben dolgozók körében $(\mathrm{n}=18)$. A testmozgást vizsgáló kérdéscsoport aspektusából elmondható, hogy 16,1\%-kal magasabb a légi mentésben dolgozók körében a rendszeres könnyű testmozgást végzők aránya $(\mathrm{n}=38)$ a földi mentésben dolgozókhoz képest $(\mathrm{n}=44)$. Az egészséggel kapcsolatos megküzdési szokások össze- sített értékei alapján a következők állapíthatók meg: a mintában szereplő földi mentésben dolgozók közül a pontok alapján „aggodalomra okot adó” kategóriába esett a csoport $34,1 \%$-a $(n=29)$. Az „elégséges” kategóriába a csoport 29,4\%-a $(\mathrm{n}=25)$, „jó” kategóriába 25,9\%-a $(n=22)$ és a „kiváló” kategóriába csupán 10,6\%a került $(n=9)$. Ezzel szemben a légi mentésben dolgozók csoportjának aránya jobbnak mutatkozott. A legrosszabb, „aggodalomra okot adó” kategóriába került a csoport 10,7\%-a $(n=6)$. Ennél több, 19,6\% az „elégséges" kategóriába $(\mathrm{n}=11)$, a csoport $50 \%$-a $(\mathrm{n}=28)$ pedig a „jó” kategóriába sorolható. A megküzdési érték alapján a „kiváló” kategóriába csupán a csoport 19,6\%-a sorolható $(\mathrm{n}=11)$. Összességében kijelenthető, hogy a légi mentésben részt vevők stresszel való megküzdési mechanizmusuk, illetve az egészséggel kapcsolatos szokások szempontjából jobbnak bizonyultak, mint a földi mentésben részt vevő kollégáik $(\mathrm{p}<0,01)$. A kérdőívben a stresszre adott válasz alskála 10 tételból áll, amely a különböző életesemények által kiváltott stresszválaszok egyéni mintázatait térképezi fel. Az „Elégedettség az élettel" alskálát 8 kérdés alkotja, amelyek a következő területekre térnek ki: általános egészségi állapot, család, munka, személyes életvitel. Az utolsó alskálát a megküzdési kapacitások tekintetében az „Életcél és kapcsolatok” dimenzió alkotja. A stresszre adott válasz szempontjából jobb megküzdési mechanizmusról $(\mathrm{p}<0,01)$, illetve elégedettebb családi, munka és egészségi állapotról $(\mathrm{p}<0,01)$ vallottak a mintában szereplő légi mentésben szolgálatot teljesítők. Az „Életcél és kapcsolatok” tekintetében jelentős különbség nem mutatkozott a két vizsgált csoport között $(\mathrm{p}=0,370)$. A minta átlagos megküzdési mutató szerinti eredményeit a 3. táblázat foglalja össze.

A következőkben arra kerestük a választ, hogy a különböző demográfiai tényezők milyen hatással vannak mind az összesített stresszmutatók, mind az összesített megküzdési mutatók alakulására. A nemek szempontjából a mintában szereplők körében a férfiak átlagos összesített stresszmutatója 6,91 ( $\mathrm{SD}=1,916)$, míg a nóknél ez az érték magasabb, 7,67 (SD = 1,435) volt. Szignifikáns különbség mutatkozott a nem és az összesített stresszmutatók viszonylatában $(\mathrm{p}<0,05)$, aminek értelmében elmondható, hogy nagyobb fokú munkahelyi stresszhatásnak vannak kitéve a mintában szereplő nők a férfi kollégáikhoz képest. A nemek szempontjából az összesített megküzdési mutatók hasonló átlagértékeket mutattak egymáshoz viszonyítva. A vizsgálatban szereplő férfiaknál ez az átlag 2,44 (SD = 0,803), míg a minta női része közel azonos copingképességekről tett tanúbizonyságot a férfiakhoz képest, mivel átlaguk 2,63 (SD = $0,711)$ volt. Itt is megvizsgáltuk, hogy van-e kapcsolat a nemek és az összesített megküzdési mutatók alakulása közt. A szórásegyezés megbizonyosodását követően azonban kiderült, hogy nem mutatkozott szignifikáns különbség a nem és az összesített megküzdési mutató szemszögéból $(\mathrm{p}=0,309)$. Az életkor szempontjából 
3. táblázat $\mid$ A minta jellemzése átlagos copingmutató szerint $(\mathrm{n}=141)$

\begin{tabular}{|c|c|c|}
\hline & \multicolumn{2}{|c|}{ Átlagos copingmutató* } \\
\hline & $\begin{array}{l}\text { Földi mentésben } \\
\text { dolgozók }\end{array}$ & $\begin{array}{l}\text { Légi mentésben } \\
\text { dolgozók }\end{array}$ \\
\hline $\begin{array}{l}\text { Egészséggel } \\
\text { kapcsolatos szokások }\end{array}$ & $\begin{array}{l}\text { Értékelés: } 1 \\
\text { (elégséges) }\end{array}$ & Értékelés: 2 (jó) \\
\hline Társas támogatottság & $\begin{array}{l}\text { Értékelés: } 1 \\
\text { (elégséges) }\end{array}$ & $\begin{array}{l}\text { Értékelés: } 1 \\
\text { (elégséges) }\end{array}$ \\
\hline $\begin{array}{l}\text { Stresszre adott } \\
\text { mentális válasz }\end{array}$ & $\begin{array}{l}\text { Értékelés: } 0 \\
\text { (aggodalomra okot } \\
\text { adó) }\end{array}$ & $\begin{array}{l}\text { Értékelés: } 1 \\
\text { (elégséges) }\end{array}$ \\
\hline $\begin{array}{l}\text { Elégedettség az } \\
\text { élettel }\end{array}$ & $\begin{array}{l}\text { Értékelés: } 1 \\
\text { (elégséges) }\end{array}$ & Értékelés: 2 (jó) \\
\hline Életcél és kapcsolatok & $\begin{array}{l}\text { Értékelés: } 0 \\
\text { (aggodalomra okot } \\
\text { adó) }\end{array}$ & $\begin{array}{l}\text { Értékelés: } 0 \\
\text { (aggodalomra okot } \\
\text { adó) }\end{array}$ \\
\hline
\end{tabular}

* A mérési skálák értékelése során a standard értékek jelentése:

3: kiváló, 2: jó, 1: elégséges, 0: aggodalomra okot adó.

A magasabb elért átlagos copingmutató hatékonyabb megküzdést jelent.

való vizsgálatra egy szempontos varianciaanalízis-elemzést végeztünk (ANOVA). A szórásegyezés megbizonyosodását követően az eredményekből kiderült, hogy az életkor nem befolyásolja sem az összesített stresszmutató $(\mathrm{p}=0,146)$, sem az összesített megküzdési mutató alakulását $(\mathrm{p}=0,228)$. Elmondható azonban, hogy a vizsgálatban szereplők azon csoportja, akik a 46-55 éves korosztályba tartoznak, hatékonyabb copingképességről tettek tanúbizonyságot. Ebben a korosztályban az átlag összesített megküzdési mutató 2,93 ( $\mathrm{SD}=0,267$ ), míg a 20-25 évesek 2,31 ( $\mathrm{SD}=0,855)$, a 26-35 évesek 2,42 $(\mathrm{SD}=0,801)$, a $36-45$ évesek $2,46(\mathrm{SD}=0,808)$ és az 56-65 évesek 2,33 ( $\mathrm{SD}=1,033$ ) pontot értek el. Hasonlóan nem mutatkozott szignifikáns különbség a társas támogatottság és a különböző összesített stressz- (p = 0,253), összesített megküzdési mutatók $(\mathrm{p}=0,081)$ között sem. Ennek függvényében kijelenthető, hogy a társas támogatottság nincs komoly hatással a stressz- és megküzdési értékek alakulására a vizsgálatban szereplők körében.

\section{Megbeszélés}

Egy olyan vizsgálatot, kutatást szerettünk volna elvégezni, amelyben nem az egészségügyi dolgozókhoz képest vizsgáljuk a mentőmunkában részt vevők állapotát. Kíváncsiak voltunk, hogy a prehospitális mentésben részt vevők csoportján belül az egymással szorosan összekapcsolódó földi és légi mentésben dolgozók egymáshoz képest milyen munkahelyi stresszhatásnak vannak kitéve, illetve mennyire hatékony megküzdési stratégiával rendelkeznek. A nem egészségügyi szférába tartozó, profitorientált munkahelyen dolgozók körében Dér Anikó és $m t s a i$ hasonló kutatást végeztek [19]. Hasonló irányú, a prehospitális ellátásban dolgozók e két csoportját vizsgáló felmérés Magyarországon ez ideig nem történt. A vizsgálat során érdekes eredmények mutatkoztak, nemcsak a két vizsgált csoport közt, hanem a földi mentésben részt vevők csoportján belül, a különböző mentőegységek szintjének aspektusában is. Az adatgyưjtés befejeztével, azok feldolgozása során fény derült arra, hogy az általunk felmért kivonuló mentődolgozók körében a földi mentésben részt vevők munkájuk során nagyobb munkahelyi stresszhatásnak vannak kitéve, mint légi mentésben dolgozó kollégáik. Eredményeinknek ezt a részét a Rózsa Sándor és mtsai által vizsgált, Rahe-féle Rövidített Stressz és Megküzdés Kérdőív hazai eredményein bemutatott vizsgálat szempontjai szerint kiszámított összesített stresszmutató alapján kaptuk [15]. Az eredményekből ugyancsak megmutatkozik, hogy a munkahelyi stressz hatására a testi és pszichológiai tünetek jelentősebb mértékben voltak jelen azoknál, akik a földi mentésben vettek részt. A földi mentésben dolgozók csoportján belül a magasabb szintü mentőegységeken szolgálók közt volt nagyobb mértékben érzékelhető a stresszhatás. Ugyancsak elmondható, hogy nagyobb munkahelyi stresszhatásnak vannak kitéve a férfiakhoz képest a nói mentődolgozók, azonban a stresszel való megküzdési mechanizmusban nem különböznek. Ebből a szemszögből egy hazai kutatás, amelyet Marton-Simora József és mtsai végeztek, hasonló eredményeket mutatott [20]. Azonban a P. Benett és mtsai által végzett brit vizsgálat ugyanezen aspektusból az ellenkező eredményre jutott, miszerint a férfi mentődolgozók körében jelentősebb a munkahelyi stressz hatása a női mentődolgozókhoz képest [3]. A stresszel való megküzdési képesség szempontjából a légi mentésben dolgozók bizonyultak eredményesebbnek. Ennek hátterében állhat az egészségesebb életmód, azon belül is a rendszeres dohányzás és alkoholfogyasztás kerülése, nyugodt körülmények közti, rendszeres étkezés, valamint a rendszeres testmozgás gyakorisága, ami bizonyíthatóan jellemzőbb volt a légi mentésben dolgozók körében. A munkahelyi stresszhatással szembeni rendszeres testmozgás és egészséges életmód hasonló fokú jótékony hatásáról számol be szintén mentődolgozók körében készült, Betlehem József és $m$ tsai által végzett hazai kutatás [1].

Következtetésként és javaslatként a következők mondhatók el: A vizsgálatban szereplő kivonuló mentésben dolgozókon belül mind a földi, mind a légi mentésben szolgálatot teljesítők közt aránytalanság áll fenn a dolgozót ért munkahelyi stresszhatás és az azzal való megküzdési mechanizmus közt. Ennek egyszerü magyarázata, hogy a stressz szintje meghaladja a megküzdési képességet. Ahhoz, hogy ez az aránytalanság a pozitív coping mutató irányába változzon, különböző javaslataink vannak. A társas támogatottság protektív hatásának hiánya egy esetleges munkahelyi teamépítő stratégiával mindenképpen fejleszthető lenne. A munkahelyi stressz csökkentésében a munkahelyek humán menedzsmentjének alapvető szerepe és érdeke is van. Fontosnak tartjuk a 
rendszeres szakmai elméleti és gyakorlati továbbképzések jelentőségét, valamint az egyén önbizalmát növelő kurzusok bevezetését. A munkahely menedzsmentjén túl az egyénnek saját megküzdési képességét kell átgondolnia, esetleg, ha szükséges, külső segítséggel tudatosan átdolgoznia, fejlesztenie.

Anyagi támogatás: A közlemény megírása, illetve a kapcsolódó kutatómunka anyagi támogatásban nem részesült.

Szerzôi munkamegosztás: Sch. B., E. D., Sz. Z.: A vizsgálat tervezése és lefolytatása. Sch. B., K. P. A., Sz. Z., R. B.: Statisztikai elemzések. R. L. B., P. R.: Irodalomkutatás. Sch. B., E. D., K. P. A., R. L. B., R. B.: A kézirat megszövegezése. A cikk végleges változatát valamennyi szerző elolvasta és jóváhagyta.

Érdekeltségek: A szerzőknek nincsenek érdekeltségeik.

\section{Irodalom}

[1] Betlehem, J., Horváth, A., Göndöcs, Zs.: Major contributing factors of self perceived health in Hungarian ambulance personnel. [A kivonuló mentődolgozók egészségi állapotát befolyásoló főbb tényezők hazánkban.] Orv. Hetil., 2010, 151(51), 2089-2098. [Hungarian]

[2] Pék, E., Nagy, G., Marton-Simora, J., et al.: Rescue workers among drug use and post-traumatic stress syndrome in context. [Élvezeti szerek és poszttraumás stressz szindróma összefüggései mentődolgozók körében.] Nővér, 2011, 24(4), 11-20. [Hungarian]

[3] Bennett, P., Williams, Y., Page, N., et al.: Levels of mental health problems among UK emergency ambulance workers. Emerg. Med. J., 2004, 21(2), 235-236.

[4] Szabó, N., Hegedüs, K., Szabó, G., et al.: Work-related stress status and social support for health care workers. [Egészségügyi dolgozók munkahelyi stresszállapota és társas támogatottsága.] Nővér, 2008, 21(1), 10-17. [Hungarian]

[5] Ádám, Sz., Nistor, A., Nistor, K., et al.: Negative and positive predictive relationships between coping strategies and the three burnout dimensions among Hungarian medical students. [A megküzdési stratégiák negatív és pozitív prediktív kapcsolata a kiégés három dimenziójával orvostanhallgatók körében.] Orv. Hetil., 2014, 155(32), 1273-1280. [Hungarian]

[6] Mészáros, V., Cserbáti, Z., Oláh, A., et al.: Coping with work-related stress in health care professionals - strategies for prevention of burnout and depression. [A munkahelyi stresszel való megküzdés egészségügyi szakdolgozók körében - lehetőségek a kiégés és depresszió megelőzésének szolgálatában.] Orv. Hetil., 2013, 154(12), 449-454. [Hungarian]

[7] Müller, A., Gál, N., Betlehem, J., et al.: Examination of the interaction of different lighting conditions and chronic mild stress in animal model. Acta Phys. Hung., 2015, 102(3), 301-310.

[8] Karamánné Pakai, A.: Stress, screening, measurement possibilities. In: Szabo, J. (ed.): Mental health protection at workplace. [A stressz, szűrés, mérési lehetőségek. In: Szabó, J. (szerk.):
Munkahelyi lelki egészségvédelem.] Pécsi Tudományegyetem, Egészségtudományi Kar, Pécs, 2014, 76-104. [Hungarian]

[9] Karamánné Pakai, A.: Coping. In: Szabo, J. (ed.): Mental health protection at workplace. [Megküzdés. In: Szabó, J. (szerk.): Munkahelyi lelki egészségvédelem.] Pécsi Tudományegyetem, Egészségtudományi Kar, Pécs, 2014, 105-107. [Hungarian]

[10] Karamánné Pakai, A.: Screening, measurement possibilities. In: Szabo, J. (ed.): Mental health protection at workplace. [Szúrés és mérési lehetőségek. In: Szabó, J. (szerk.): Munkahelyi lelki egészségvédelem.] Pécsi Tudományegyetem, Egészségtudományi Kar, Pécs, 2014, 108-120.[Hungarian]

[11] Karamánné Pakai, A.: Stress management at individual and organization levels. In: Szabo, J. (ed.): Mental health protection at workplace. Training topics. [Stresszkezelés egyéni és szervezeti szinten. In: Szabó, J. (szerk.): Munkahelyi lelki egészségvédelem. Tréningtematika.] Pécsi Tudományegyetem, Egészségtudományi Kar, Pécs, 2014, 42-84. [Hungarian]

[12] Szabó, J. (ed.): Mental health protection at workplace. Handbook for education and consultation. [Munkahelyi lelki egészségvédelem. Képzési és tanácsadási kézikönyv.] Pécsi Tudományegyetem, Egészségtudományi Kar, Pécs, 2014. [Hungarian]

[13] Szabo, J. (ed.): Mental health protection at workplace. Training topics. [Munkahelyi lelki egészségvédelem. Tréningtematika.] Pécsi Tudományegyetem, Egészségtudományi Kar, Pécs, 2014. [Hungarian]

[14] Szabó, J., Pék, E., Betlehem, J.: The importance of social support in the development of health. [A társas támogatottság jelentősége az egészségi állapot alakulásában.] Egészségakadémia, 2011, 2(2), 99-106. [Hungarian]

[15] Rózsa, S., Kö, N., Csoboth, Cs., et al.: Stress and coping. Hungarian experiences with Rahe Brief Stress and Coping Inventory. [Stressz és megküzdés. A Rahe-féle Rövidített Stressz és Megküzdés Kérdő́ivvel szerzett hazai eredmények ismertetése.] Mentálhigiéné és Pszichoszomatika, 2005, 6(4), 275-294. [Hungarian]

[16] Ács, P., Oláh, A., Karamánné Pakai, A., et al.: Practical data analysis. [Gyakorlati adatelemzés.] Pécsi Tudományegyetem, Egészségtudományi Kar, Pécs, 2014. [Hungarian]

[17] Lampek, K., Kivés, Zs.: Research methodology and biostatistics. In: Oláh, A. (ed.): Nursing textbook. [Kutatásmódszertani és biostatisztikai ismeretek. In: Oláh, A. (szerk.): Az ápolástudomány tankönyve.] Medicina Könyvkiadó, Budapest, 2012. [Hungarian]

[18] Pakai, A., Kivés, Zs.: About research for nurses. Sampling and data collection methods in health sciences research. [Kutatásról ápolóknak: Mintavétel és adatgyújtési módszerek az egészségtudományi kutatásokban.] Nővér, 2013, 26(3), 20-43. [Hungarian]

[19] Dér, A., Karamánné Pakai, A., Németh, K. et al.: Chronic stress among workers in for-profit workplace. [Krónikus stressz vizsgálata profitorientált munkahelyen dolgozók körében.] Magyar Orvos, 2009, 17(1-2), 36-40. [Hungarian]

[20] Marton-Simora, J., Gyermény, O., Betlehem, J., et al.: Post-traumatic stress among emergency workers in Budapest. [Poszttraumás stressz a budapesti mentődolgozók körében.] Nővér, 2008, 21(4), 10-19. [Hungarian]

(Schiszler Bence, Högyész, Vadász u. 16., 7191 e-mail: schiszlerbence89@gmail.com) 